\title{
Fragmentation studies of tetrahydropyridocarbazole derivatives by EI, ESI-MS/MS and FAB
}

\author{
Gilberto A. Romeiro a,*, Vitor F. Ferreira a , Marília dos S. Costa ${ }^{\text {a }}$, Alexandre M. Joaquim ${ }^{\text {a }}$, \\ José Walkimar de M. Carneiro ${ }^{a}$ and Bernd Kammerer ${ }^{\mathrm{b}}$

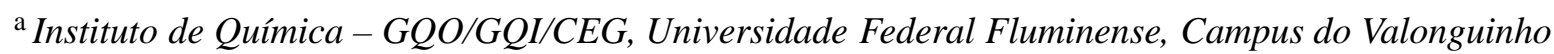 \\ S/N, Niteröi, CEP 24210-150, RJ, Brazil \\ ${ }^{\mathrm{b}}$ Institut für Organische Chemie, Universität Tübingen, Auf der Morgenstelle 18, D-72076 Tübingen, \\ Germany
}

\begin{abstract}
Four tetrahydropyridocarbazole derivatives were analysed by different mass spectrometry techniques: electrospray ionization, fast atom bombardment and by low and high resolution $70 \mathrm{eV}$ electron ionization. Retro Diels Alder is the main fragmentation pathway, whereas other pathways leading to $[\mathrm{M}-1]^{+},\left[\mathrm{M}-\mathrm{CH}_{3}\right]^{+}$and double charge ions also occur to considerable extents. Semi-empirical calculation provided some evidence on the nature of tropylium ions $[\mathrm{M}-1]^{+}$. Calculation of $\Delta \mathrm{Hf}^{0}$ indicated that $\left[\mathrm{M}^{+}-1\right]$ could be formed preferentially when a hydrogen atom is lost from the methyl substituent of the homoaromatic ring.
\end{abstract}

\section{Introduction}

Ellipiticine and olivacine are two important pyridocarbazoles alkaloids that exhibit antitumor activity and their synthetic routes [1] and biological activity [2,3] have been widely studied. Although the pyridocarbazole system is present in several important compounds, few mass spectrometry studies have been performed on their fragmentation pattern.

Continuing our work toward the synthesis of substances with antitumor activity we synthesized new angular derivatives of pyridocarbazoles starting from alkylquinolines. Here we describe the preparation of 1-4 (Fig. 1) and report our results on their fragmentation pattern by EI, ESI-MS/MS and FAB.

\section{Experimental}

The infrared spectra were recorded in a Perkin Elmer model 1420 instrument. The nuclear magnetic resonance spectra, ${ }^{13} \mathrm{C}$ and ${ }^{1} \mathrm{H}$, were obtained from a Varian-Unity Plus instrument $\left(300 \mathrm{MHz}\right.$ for ${ }^{1} \mathrm{H}$ and $75.0 \mathrm{MHz}$ for ${ }^{13} \mathrm{C}$ ). Elemental analysis were obtained using a Carlo Erba instrument model 1104. Low-resolution EI mass spectra were recorded on a Finnigan MAT 711A instrument. The ionization energy used was $70 \mathrm{eV}$ with the source at $200^{\circ} \mathrm{C}$ and with an accelerating voltage of $8 \mathrm{kV}$. Samples were introduced by the standard direct insertion probe. High resolution data were obtained with the same

\footnotetext{
* Corresponding author.
} 
<smiles>Cc1cc(C)c2c(n1)c(C)cc1c3c([nH]c12)CCCC3</smiles>

1<smiles>Cc1cc(C)c2c(n1)c(C)cc1[nH]c3c(c12)CCCC3</smiles>

2

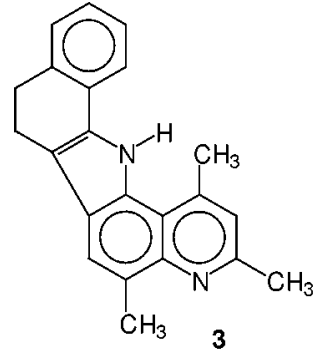

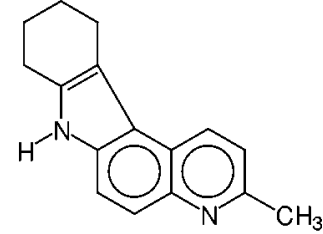

4

Fig. 1. Pyridocarbazoles 1-4.

instrument using 10,000 resolution. FAB positive-ion mass spectra were recorded on a Finnigan MATTSQ 70 triple quadrupole mass spectrometer. For FAB analysis, $m$-nitrobenzyl alcohol (NBA) was used as the matrix. Xenon was used to generate the bombarding atoms and the FAB gun was operated at $2 \mathrm{~mA}$ emission, providing fast atoms with an energy of $10 \mathrm{kV}$. Ionspray mass spectra were acquired with a triple quadrupole instrument, Perkin Elmer (API III TAGA 6000E) equipped with a ionspray source (Sciex, Toronto, Canada). Samples were infused into the electronspray source, in methanol solution, using a syringe inlet. The semi-empirical calculation were performed using the AM1 [23] and PM3 [24] methods as implemented in the MOPAC 93 program [25]. All geometries were fully optimized using the EigenVector following optimization routine [26] until the gradient norm dropped bellow 0.05 . Geometry optimizations were followed by frequency calculations to certify that the geometries found are true minima.

\subsection{Chemicals}

Compounds 1,3,5-trimethyl-7,8,9,10-tetrahydro-11H-pyrido[3,2-a ]carbazole (1), 1,3,5-trimethyl-8,9, 10,11-tetrahydro-7H-pyrido[2,3-c]carbazole (2), 1,3,5-trimethyl-7,8-dihydro-13H-benzo[1]pyrido[2, 3-ç]carbazole (3) and 3-methyl-8,9,10,11-tetrahydro-7H-pyrido[2,3-c]carbazole (4) were synthesized using 2,4,8-trimethyl-5-aminoquinoline, 2,4,5,8-tetramethyl-6-aminoquinoline, 2,4,8-trimethyl-5-aminoquinoline and 2-methyl-6-aminoquinoline, respectively, as starting material in the Fischer indole synthesis. Compounds 1, 2 and $\mathbf{4}$ were synthesized using cyclohexanone in the last step, while $\alpha$-tetralone was used for 3 . The structures of the starting aminoquinolines were establish by using ${ }^{1} \mathrm{H}$ and ${ }^{13} \mathrm{C}$ techniques.

\subsection{General procedure}

To a solution of the appropriated alkylaminoquinoline (2,4,8-trimethyl-5-aminoquinoline, 2,4,5,8tetramethyl-6-aminoquinoline or 2-methyl-6-aminoquinoline) (10 mmoles) and $2 \mathrm{ml}$ of concentrated hydrochloric acid externally cooled to $0^{\circ} \mathrm{C}$, an aqueous solution of sodium nitrite (11 mmoles) was added. The reactional mixture was stirred for $30 \mathrm{~min}$ and then the resulting diazonium salt was slowly added to a solution of stannous chloride ( 26 mmoles) in concentrated hydrochloric acid. The mixture was stirred for $1 \mathrm{~h}$ at room temperature and then added $10 \mathrm{ml}$ of glacial acetic. The was raised to $80^{\circ} \mathrm{C}$ and kept constant for $4 \mathrm{~h}$. The solution was cooled down to room temperature and solid filtered, washed with water $(20 \mathrm{ml})$, sodium hydroxide solution $(20 \mathrm{ml}, 50 \% \mathrm{~W} / \mathrm{V})$, water $(20 \mathrm{ml})$, air dried and recrystallized in ethanol to yield the compounds: 
1,3,5-Trimethyl-7,8,9,10-tetrahydro-11H-pyrido[3,2-a] carbazole (1). Obtained in 40\% yield; m.p. $180^{\circ} \mathrm{C}$; IR $(\mathrm{KBr}) \mathrm{cm}^{-1}-3400(\mathrm{NH}), 2960,2840,1600,1570,1460,1360,1340,1320,1230,1160$, $1030,860,840 ;{ }^{1} \mathrm{H}-\mathrm{NMR}\left(\mathrm{CDCl}_{3}\right) \delta 1.80-2.00\left(\mathrm{~m}, 4 \mathrm{H}, 2 \mathrm{CH}_{2}\right), 2.62\left(\mathrm{~s}, 3 \mathrm{H}, \mathrm{CH}_{3}\right), 2.72-2.76(2 \mathrm{~s}, 10 \mathrm{H}$, $\left.2 \mathrm{CH}_{3}, 2 \mathrm{CH}_{2}\right), 6.90(\mathrm{~s}, 1 \mathrm{H}, \mathrm{Ar}), 7.50(\mathrm{~s}, 1 \mathrm{H}, \mathrm{Ar}), 8.26(1,1 \mathrm{H}, \mathrm{NH}) \mathrm{ppm} ;{ }^{13} \mathrm{C}-\mathrm{NMR}\left(\mathrm{CDCl}_{3}\right) \delta 0.67,0.87$, $1.07,1.26,2.24,19.33,20.88,22.37,22.65,23.42,24.41,25.00,110.93,121.08,122.04,127.83,132.71$, 139.83 ppm; Anal. Calcd. for $\mathrm{C}_{18} \mathrm{H}_{20} \mathrm{~N}_{2}$ : C-81.81, H-7.57, N-10.6, found C-80.90, H-7.43, N-10.04.

1,3,5-Trimethyl-8,9,10,11-tetrahydro-7H-pyrido[2,3-c]carbazole (2). Obtained in 25\% yield; m.p. $197-199^{\circ} \mathrm{C}$; IR $(\mathrm{KBr}) \mathrm{cm}^{-1} 3140(\mathrm{NH}), 1590,1580 ; 1^{1} \mathrm{H}-\mathrm{NMR}\left(\mathrm{MHz}, \mathrm{CDCl}_{3}\right) \delta 1.70-2.20(\mathrm{~m}, 4 \mathrm{H}$, $\left.2 \mathrm{CH}_{2}\right), 2.47\left(\mathrm{~s}, 3 \mathrm{H}, \mathrm{CH}_{3}\right), 2.67-2.74\left(2 \mathrm{~s}, 10 \mathrm{H}, 2 \mathrm{CH}_{3}, 2 \mathrm{CH}_{2}\right), 6.83$ (s, $\left.1 \mathrm{H}, \mathrm{Ar}\right), 7.52(\mathrm{~s}, 1 \mathrm{H}, \mathrm{Ar}), 8.40$ (l, $1 \mathrm{H}, \mathrm{NH}) \mathrm{ppm} ;{ }^{13} \mathrm{C}-\mathrm{NMR}\left(\mathrm{MHz}, \mathrm{CDCl}_{3}\right) \delta 0.72,0.85,1.17,1.22,2.36,19.37,20.80,21.95,22.45,24.41$, 25.40, 25.65, 112.43, 121.05, 122.17, 127.82, 133.01, 139.80 ppm; Anal. Calcd. for $\mathrm{C}_{18} \mathrm{H}_{20} \mathrm{~N}_{2}$ : C-81.81, H-7.57, N-10.6, found C-80.75, H-7.82, N-10.04.

1,3,5-Trimethyl-7,8-dihydro-13H-benzo[l]pyrido[2,3-ç]carbazole (3). Obtained in 55\% yield; m.p. $205^{\circ} \mathrm{C}$; IR (KBr) cm ${ }^{-1} 3550(\mathrm{NH}), 2960,2850,1620,1460,1420,1340,1300,880,840,760 ;{ }^{1} \mathrm{H}-\mathrm{NMR}$ $\left(\mathrm{CDCl}_{3}\right) \delta 2.0\left(\mathrm{~s}, 3 \mathrm{H}, \mathrm{CH}_{3}\right), 2.72\left(\mathrm{~s}, 4 \mathrm{H}, 2 \mathrm{CH}_{2}\right), 2.74\left(\mathrm{~s}, 3 \mathrm{H}, \mathrm{CH}_{3}\right), 2.96\left(\mathrm{~s}, 3 \mathrm{H}, \mathrm{CH}_{3}\right), 6.94(\mathrm{~s}, 1 \mathrm{H}, \mathrm{Ar})$, 7.06-7.30 (m, 4H, Ar), $7.58(\mathrm{~s}, 1 \mathrm{H}, \mathrm{Ar}), 8.64(\mathrm{l}, 1 \mathrm{H}, \mathrm{NH}) \mathrm{ppm} ;{ }^{13} \mathrm{C}-\mathrm{NMR}\left(\mathrm{CDCl}_{3}\right) \delta 17.37,17.66,20.59$, 23.14, 27.63, 111.31, 113.76, 117.27, 119.36, 120.40, 120.98, 124.40, 124.69, 126.64, 126.94, 127.13, 128.11, 129.97, 134.05, 137.98, 144.13, 152.23 ppm; Anal. Calcd. for $\mathrm{C}_{22} \mathrm{H}_{20} \mathrm{~N}_{2}$ : C-82.01, H-7.81, N10.07, found C-81.23, H-7.82, N-9.94.

3-Methyl-8,9,10,11-tetrahydro-7H-pyrido[2,3-ç]carbazole (4). Obtained in $70 \%$ yield; m.p. $208^{\circ} \mathrm{C}$; IR $(\mathrm{KBr}) \mathrm{cm}^{-1} 3200-3100(\mathrm{NH}), 2900,2825,{ }^{1} \mathrm{H}-\mathrm{NMR}\left(200.13 \mathrm{MHz}, \mathrm{CDCl}_{3}\right) \delta 2.75(\mathrm{~s}), 7.30(1 \mathrm{H}, \mathrm{d}$, $\mathrm{J}=8.52 \mathrm{~Hz}), 7.62(1 \mathrm{H}, \mathrm{d}, \mathrm{J}=9.0 \mathrm{~Hz}), 7.76(1 \mathrm{H}, \mathrm{d}, \mathrm{J}=9.0 \mathrm{~Hz}), 8.43(1 \mathrm{H}, \mathrm{sl}, \mathrm{NH}), 8.56(1 \mathrm{H}, \mathrm{d}$, $\mathrm{J}=8.5 \mathrm{~Hz})$ ppm; ${ }^{13} \mathrm{C}-\mathrm{NMR}\left(\mathrm{MHz}, \mathrm{CDCl}_{3}\right) \delta 23.78\left(\underline{\mathrm{CH}}_{2}\right), 23.39\left(\underline{\mathrm{CH}}_{2}\right), 23.25\left(\underline{\mathrm{CH}}_{2}\right), 22.51\left(\underline{\mathrm{CH}}_{2}\right)$, $24.47\left(\mathrm{CH}_{3}\right), 111.99,120.07,121.68,131.00,133.80,144.36,154.00 \mathrm{ppm}$; Anal. Calcd. for $\mathrm{C}_{16} \mathrm{H}_{16} \mathrm{~N}_{2}$ : C-81.35, H-6.77, N-11.86, found C-80.74, H-6.06, N-11.04.

\section{Results and discussion}

The usual preparation of these substances is based on the well known Fischer indole cyclization between an acyclic or cyclic ketone and appropriated hydrazine derivative of quinoline. Then an appropriated alkylaminoquinoline, 2,4,8-trimethyl-5-aminoquinoline, 2,4,5,8-tetramethyl-6-aminoquinoline or 2methyl-6-aminoquinoline is diazotized and reduced in situ to give the hydrazine which was not isolated. When the hydrazine was reacted with cyclohexanone or $\alpha$-tetralone the only product obtained were the angular tetrahydropyridocarbazoles 1-4. During the preparation of compound $\mathbf{2}$ the methyl group at position 5 was eliminated. Although this is an unusual result, similar observation had been already reported in the literature.

\subsection{Mass spectrometry studies}

Compounds 1, 2 and 4 in EI showed high intensities for the molecular ion $\mathrm{M}^{+}$. and the retro Diels Alder (RDA) ion, and low intensities for the $[\mathrm{M}-1]^{+}$ion. Compound $\mathbf{3}$ produced intense molecular and $[\mathrm{M}-1]^{+}$ions and no measurable RDA ion (Table 1).

ESI-MS/MS, FAB and EI mass spectrometry [4-11] techniques were used to investigate the competitive RDA fragmentation (1a) and a possible pathway leading to the azatropyliumion (1c) (Fig. 2). To 
Table 1

Electron ionization $(70 \mathrm{eV})$ spectra data for $\mathbf{1 - 4}$

\begin{tabular}{ccccl}
\hline Compound & $\mathrm{M}^{+\cdot}$ & {$[\mathrm{M}-1]^{+}$} & {$[\mathrm{M}-28]^{+}$} & Others $m / z$ \\
\hline $\mathbf{1}$ & $264(100)$ & $263(21)$ & $236(90)$ & $265(20), 266(3), 132(18), 118(30)$ \\
$\mathbf{2}$ & $264(100)$ & $263(21)$ & $236(85)$ & $265(18), 266(2), 205(3), 186(10), 185(12), 132(18), 118(37)$ \\
$\mathbf{3}$ & $312(100)$ & $311(92)$ & None & $313(27), 314(3), 297(4), 293(2), 156(32), 155(43)$ \\
$\mathbf{4}$ & $236(97)$ & $235(24)$ & $208(100)$ & $237(18), 238(2), 209(17), 118(10), 104(7)$. \\
\hline
\end{tabular}

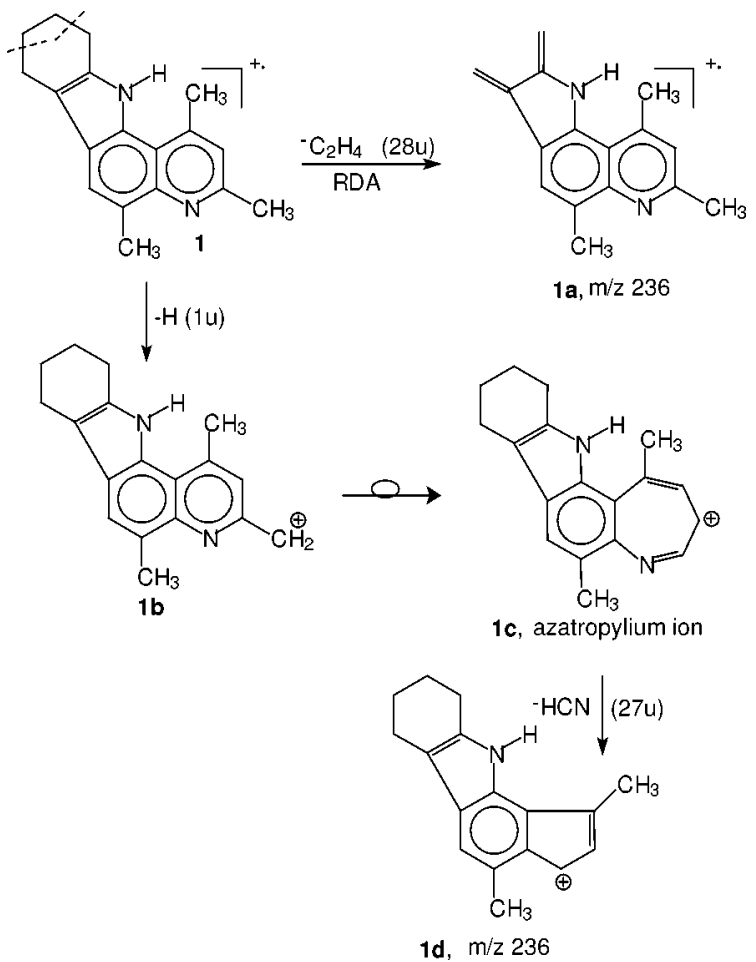

Fig. 2. Two possible pathways for the fragmentation of $\mathbf{1}$.

confirm that an ethylene molecule is lost when the $[\mathrm{M}-28]^{+}$ions are formed, high resolution mass spectra were obtained (Table 2). Indeed, the fragments $[\mathrm{M}-28]^{+}$were consistent with $\left[\mathrm{M}-\mathrm{C}_{2} \mathrm{H}_{4}\right]^{+}$and not with $[\mathrm{M}-\mathrm{H}-\mathrm{HCN}]^{+}$. Another evidence for the RDA fragmentation of $\mathbf{1 , 2}$ and $\mathbf{4}$ is the absence of the RDA fragment for $\mathbf{3}$ suppressed by its condensed benzene ring.

The FAB mass spectra of 1-4 (Table 3) show mainly the molecular ion $\mathrm{M}^{+\cdot}$, which is not so often observed in FAB spectra [12-15], the protonated molecule $[\mathrm{M}+1]^{+}$, the $[\mathrm{M}-1]^{+}$and the $[\mathrm{M}-28]^{+}$ RDA fragments. FAB generates the RDA fragment in moderate intensity for $\mathbf{1}, \mathbf{2}$ and $\mathbf{4}$.

Table 4 reports the ESI-MS spectra of $\mathbf{1 - 4}$, in which the RDA fragment $[\mathrm{M}-28]^{+}$was also observed for 1, 2, and 4. RDA also occurs from $\mathrm{MH}^{+}$by collision-induced dissociation (CID). When the protonated molecule is subjected to ESI-MS/MS, those for $\mathbf{1}, \mathbf{2}$ and $\mathbf{4}$ form the RDA ion as the major fragment (spectra not shown).

The RDA fragment of $m / z 236$ from both $\mathbf{1}$ and 2, also subjected to CID, forms $m / z 221$ by methyl loss, a fragment of $m / z 206$ by $\mathrm{CH}_{2} \mathrm{O}$ loss, and a fragment of $\mathrm{m} / z 194$ by the combined loss of $\left[\mathrm{H}+\mathrm{CH}_{3} \mathrm{CN}\right]$. 
Table 2

High Resolution (HR) data for $\mathrm{M}^{+\cdot}$ and $[\mathrm{M}-28]^{+}$fragments

\begin{tabular}{|c|c|c|c|c|}
\hline Compound & & $\mathrm{HR} \mathrm{M}^{+\cdot}$ & & $\mathrm{HR}[\mathrm{M}-28]^{+}$ \\
\hline 1 & $\mathrm{C}_{18} \mathrm{H}_{20} \mathrm{~N}_{2}$ & $264.16265(\Delta=0.00095)$ & $\mathrm{C}_{16} \mathrm{H}_{16} \mathrm{~N}_{2}$ & $236.1306(\Delta=0.00075)$ \\
\hline 2 & $\mathrm{C}_{18} \mathrm{H}_{20} \mathrm{~N}_{2}$ & $264.16265(\Delta=0.00047)$ & $\mathrm{C}_{16} \mathrm{H}_{16} \mathrm{~N}_{2}$ & $236.1313(\Delta=0.00005)$ \\
\hline 3 & $\mathrm{C}_{22} \mathrm{H}_{20} \mathrm{~N}_{2}$ & $312.1626 \quad(\Delta=0.00005)$ & - & - \\
\hline 4 & $\mathrm{C}_{16} \mathrm{H}_{16} \mathrm{~N}_{2}$ & $236.1304 \quad(\Delta=0.00095)$ & $\mathrm{C}_{14} \mathrm{H}_{12} \mathrm{~N}_{2}$ & $208.1011(\Delta=0.00105)$ \\
\hline
\end{tabular}

Table 3

FAB mass spectra of $\mathbf{1}-\mathbf{4}$ in a matrix of NBA

\begin{tabular}{ccccc}
\hline Compound & $\mathrm{M}^{+\cdot}$ & {$[\mathrm{M}+1]^{+}$} & {$[\mathrm{M}-1]^{+}$} & RDA \\
\hline $\mathbf{1}$ & $264(100)$ & $265(86)$ & $263(60)$ & $236(52)$ \\
$\mathbf{2}$ & $264(100)$ & $265(87)$ & $263(50)$ & $236(40)$ \\
$\mathbf{3}$ & $312(100)$ & $313(58)$ & $311(70)$ & None \\
$\mathbf{4}$ & $236(62)$ & $237(100)$ & $235(23)$ & $208(24)$ \\
\hline
\end{tabular}

Table 4

ESI-MS mass spectra of $\mathbf{1 - 4}$

\begin{tabular}{ccc}
\hline Compound & {$[\mathrm{M}+1]^{+}$} & RDA \\
\hline $\mathbf{1}$ & $265(82)$ & $236(72)$ \\
$\mathbf{2}$ & $265(92)$ & $236(48)$ \\
$\mathbf{3}$ & $313(67)$ & None \\
$\mathbf{4}$ & $237(100)$ & $208(45)$ \\
\hline
\end{tabular}

The $[\mathrm{M}-1]^{+}$fragment is observed by EI (Table 1) and FAB (Table 3). Hydrogen loss is common for benzyl derivatives [16-18], methylquinolines and isoquinolines [19-21]. However, when a methyl group is attached to the homoaromatic ring the rearrangement of the benzyl cation to the tropylium ion often occurs, and when the methyl group is attached to the pyridine ring, the analogous azatropylium ion is observed. These alternative dissociations are exemplified for the model compound 2,4,8-trimethylquinoline $\mathbf{5}$ in Fig. 3, yielding either the tropylium ion $\mathbf{5 f}$ or the azatropylium ion $\mathbf{5 b}$ or $\mathbf{5 d}$.

Draper and Maclean [22] studied the azatropylium mechanism by deuterium labeling dimethylquinoline. They suggested hydrogen atom loss and ring expansion, followed by loss of $\mathrm{CH}_{3} \mathrm{CN}$ or $\mathrm{HCN}$. However, our results showed that the loss of hydrogen atom occurred but without HCN loss [?].

To stablish the more favorable $\mathrm{H}$ atom loss from $\mathrm{M}^{+\cdot}$ (Fig. 3), we performed semi-empirical AM1 and PM3 calculations for the model ions $\mathbf{5 a}-\mathbf{f}$.

Both the AM1 and PM3 results (Table 5) indicate thatthe most stable $[\mathrm{M}-\mathrm{H}]^{+}$ion is $\mathbf{5 e}$, that formed when the hydrogen atom is lost from the methyl group at position 8. Loss of a hydrogen atom from the methyl group in positions $2(\mathbf{5 a})$ or $4(\mathbf{5 c})$ leads to ions that are at least $10 \mathrm{kcal} / \mathrm{mol}$ less stable than $\mathbf{5 e}$. Similarly, the tropylium ion $\mathbf{5 f}$ formed from $\mathbf{5 e}$ is more stable by near $5 \mathrm{kcal} / \mathrm{mol}$ than that originated from the rearrangement of the cation of position $2(\mathbf{5 b})$ or $4(\mathbf{5 d})$.

This finding for the model compound 5 suggests that the $m / z[\mathbf{M}-1]^{+}$in the tetrahydropyridocarbazoles $\mathbf{1}, \mathbf{2}$ and $\mathbf{3}$ correspond to $\mathrm{H}$ loss from the methyl group attached to the homoaromatic ring. Compounds 1, 2 and $\mathbf{4}$ (Table 1) also show doubly charged $\mathrm{M}^{2+}$ and $[\mathrm{M}-28]^{2+}$ ions, the latter corresponding to RDA fragmentation of $\mathrm{M}^{2+}$. Compound 3 shows two doubly charged ions, $m / z 156[\mathrm{M}]^{2+}$ and $155[\mathrm{M}-1]^{2+}$. 


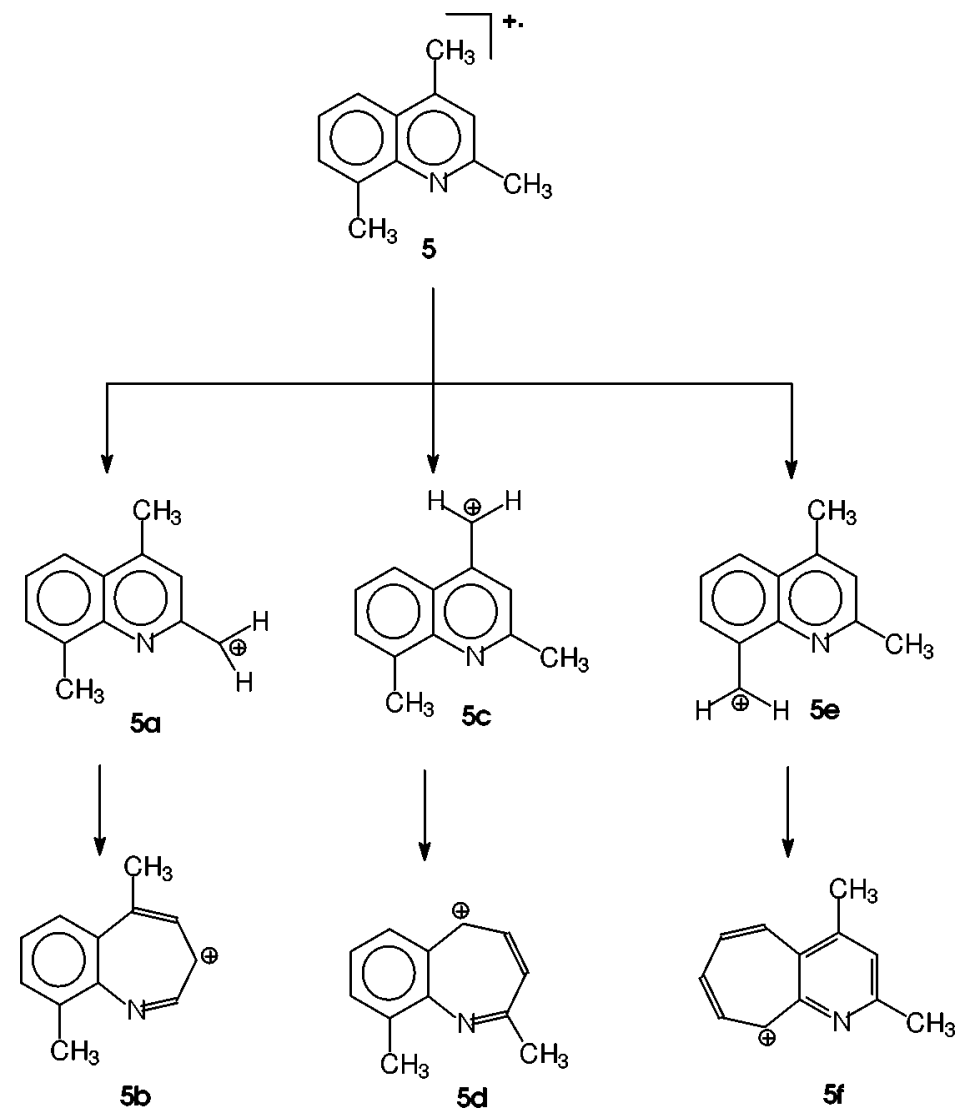

Fig. 3. Possible pathways for $\mathrm{H}$ loss of the model compound 5.

Table 5

Semi-empirical calculations using AM1 and PM3 methods for the ions formed upon the H loss from 5

\begin{tabular}{rrr}
\hline $\mathbf{5}$ & & $\Delta \mathrm{Hf}^{0}(\mathrm{kcal} / \mathrm{mol}) \mathrm{PM} 3$ \\
$\mathbf{5 b}$ & & \\
$\mathbf{5 c}$ & 243.45 & 234.94 \\
$\mathbf{5 d}$ & 242.61 & 230.37 \\
$\mathbf{5 e}$ & 231.33 & 229.13 \\
$\mathbf{5 f}$ & 227.60 & 223.13 \\
& 227.33 & 223.81 \\
\hline
\end{tabular}

\section{Conclusions}

This study showed that the $[\mathrm{M}-28]^{+}$fragment ions of tetrahydropyridocarbazolesare formed by RDA fragmentation. Although the formation of azatropylium was observed, it was not possible establish it subsequent loss of HCN. Semi-empirical calculation provided some evidence on the nature of tropy- 
lium ions $[\mathrm{M}-1]^{+}$. Calculation of $\Delta \mathrm{Hf}^{0}$ indicated that $\left[\mathrm{M}^{+}-1\right]$ could be formed preferentially when a hydrogen atom is lost from the methyl substituent of the homoaromatic ring.

\section{Acknowledgements}

We would like to acknowledge the University of Tübingen for the provision of the equipment used in this study. GAR acknowledges support from Fundação Coordenação de Nível superior (CAPES) of Brazil.

\section{References}

[1] M. Sainsbury, Synthesis 437 (1977).

[2] H. Tadashi, K. Mika, I. Minako, S. Tetsuo, S. Keiyuu, N. Toshihiro, Y. Takako and N. Teruhisa, J. Med. Chem. 31 (1988), 1295.

[3] C. Garbay-Jaureguiberry, M.C. Barsi, A. Jacquemin, J.B. Le Pecq and B.P. Roques, J. Med. Chem. 35 (1992), 72.

[4] A. Karpati, A. Rave, J. Deutsch and A. Mandelbaum, J. Am. Chem. Soc. 27 (1973), 4244.

[5] P. Bel and A. Mandelbaum, Org. Mass Spectrom. 16 (1981), 513.

[6] K.P. Madhusudanan, T.S. Dhami and A. Rani, Rapid Commun. Mass Spectrom. 7 (1993), 92.

[7] D.J. Burinsky, R. Dunphy and J.D. Alves-Santana, Org. Mass Spectrom. 26 (1991), 7, 69.

[8] K. Rogers, J. Milnes and J. Gormally, Int. J. Mass Spectrom. 121 (1992), 241.

[9] K. Pihlaja, M. Himottu and G. Stajer, Rapid Commun. Mass Spectrom. 11 (1997), 249.

[10] M. Soni, J. Amy and J.C. Schwartz, Rapid Commun. Mass Spectrom. 9 (1995), 383.

[11] M. Takayama, M. Iwamura and S. Fuchibe, Org. Mass Spectrom. 29 (1994), 601.

[12] M. Takayama, Y. Tanaka and T. Nomura, Org. Mass Spectrom. 28 (1993), 1529.

[13] H. Nakata and K. Tanaka, Org. Mass Spectrom. 29 (1994), 283.

[14] M. Takayama, J. Am. Soc. Mass Spectrom. 6 (1995), 114.

[15] P.N. Rylander, S. Meyerson and H.M. Grubb, J. Am. Chem. Soc. 79 (1957), 842.

[16] K. Levsen, in: Fundamental Aspects of Organic Mass Spectrometry, Progress in Mass Spectrometry, Vol. 4, H. Budzikiewicz, ed. Verlag Chemie, Weinheim, 1978, chapter V.

[17] H. Schwarz, Org. Mass Spectrom. 15 (1980), 491.

[18] A. Venema, N.M.M. Nibbering and Th.J. De Boer, Tetrahedron Lett. (1971), 2141.

[19] P.M. Draper and D.B. Maclean, Can. J. Chem. 46 (1968), 1487.

[20] F.R. Stermitz and C.C. Wei, J. Am. Chem. Soc. 91 (1969), 3103.

[21] S.D. Sample, D.A. Lightner, O. Buchardt and C. Djerassi, Tetrahedron 32 (1967), 997.

[22] P.M. Draper and D.B. Maclean, Can. J. Chem. 48 (1970), 738.

[23] M.J.S. Dewar, E.G. Zoebisch, E.F. Healy, J.J.P. Stewart, J. Am. Chem. Soc. 107 (1985), 3902.

[24] J.J.P. Stewart, J. Comp. Chem. 10 (1989), 210.

[25] MOPAC 93, QCPE program.

[26] J. Baker, J. Comp. Chem. 7 (1986), 385. 


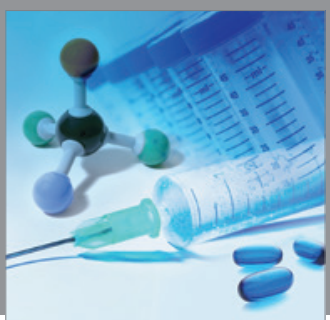

International Journal of

Medicinal Chemistry

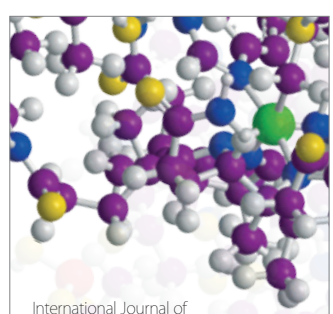

Carbohydrate Chemistry

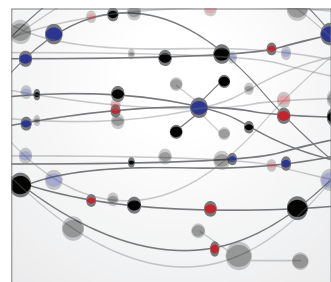

The Scientific World Journal
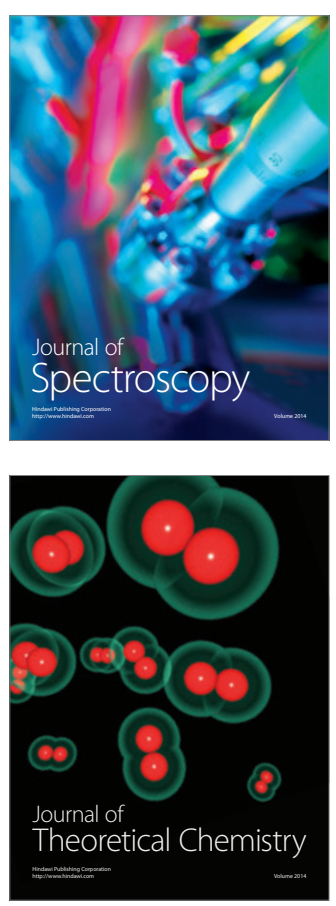
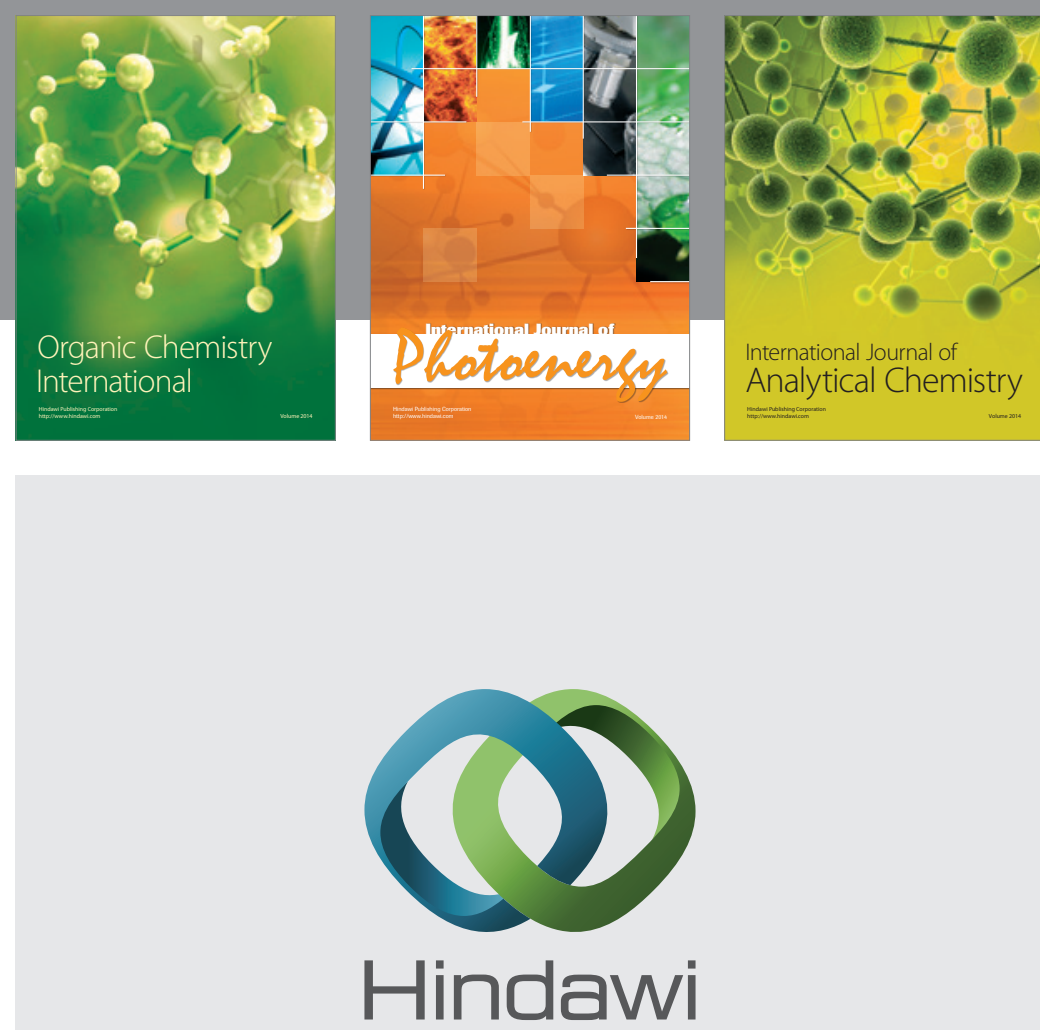

Submit your manuscripts at

http://www.hindawi.com
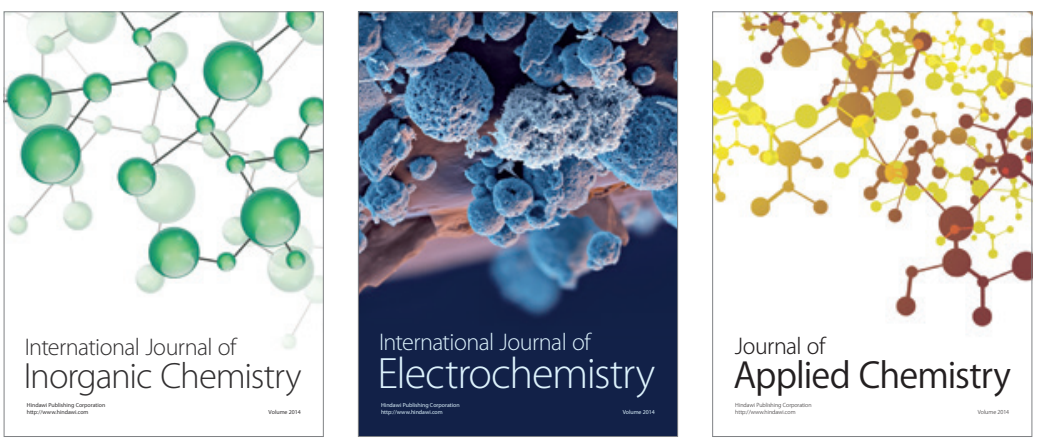

Journal of

Applied Chemistry
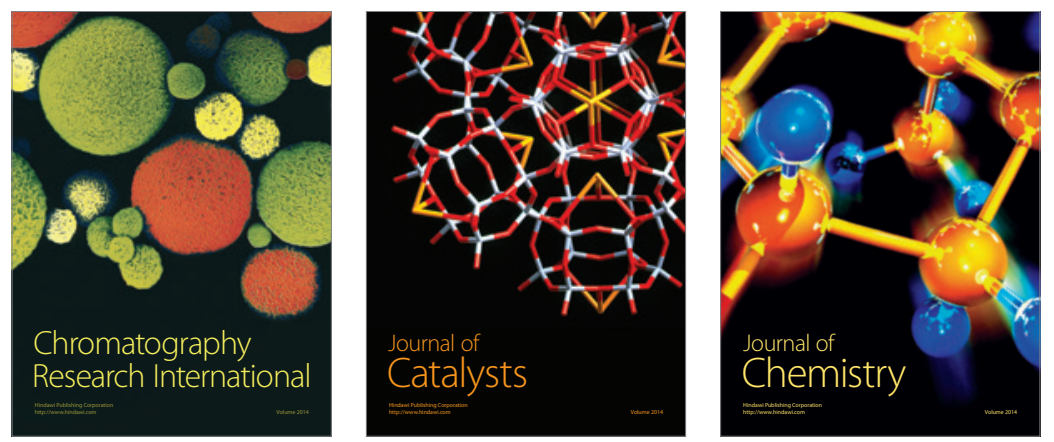
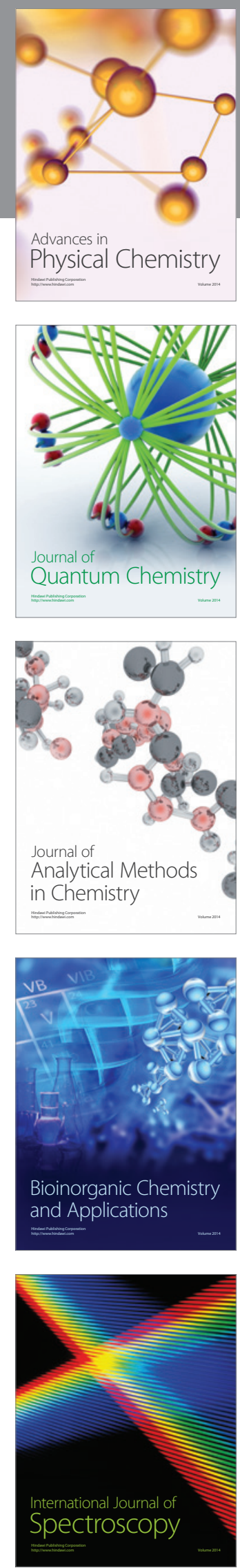